\title{
CONHECIMENTOS QUE DIALOGAM
}

\author{
Calundu - Grupo de Estudos sobre Religiões Afro-Brasileiras ${ }^{1}$
}

DOI: $10.26512 /$ revistacalundu.v3i1.25241

Reza a lenda que o Brasil foi descoberto por portugueses. Todavia, como toda lenda, esta não é inteiramente verdade. Quando portugueses tomaram conhecimento da existência de terra nesta região do mundo que chamamos de Brasil, já havia por aqui diversos povos, com vidas coletivas estruturadas, com suas culturas próprias e maneiras complexas de compreensão do mundo e de tudo que há nele. A esses povos convencionou-se chamar de indígenas. A descoberta, portanto, significou uma tomada de conhecimento por europeus sobre a existência de um lugar, habitado por pessoas diferentes deles, e consequente chegada dos europeus nesse lugar. Para os indígenas que por aqui já estavam, marcou o início de uma tragédia humanitária, que importantes humanistas (i.e. filósofos e cientistas sociais ligados aos estudos subalternos, às epistemologias e pós-colonialismo do Sul) vêm, no presente, chamando de invasão colonial - termo que aqui também adotaremos.

A invasão colonial portuguesa foi, assim, marcada por um conflito de origem: a dominação e subjugação dos indígenas. Estes foram submetidos, via violência, a um regime de trabalho forçado, que buscava tirar proveito de seus conhecimentos sobre a flora local e capacidade extrativista. E como nenhum povo se submete passivamente à dominação por outro povo, a força também foi usada para aprisionar os indígenas, de modo que não fugissem. Criou-se, com isso, o cativeiro humano em terras brasileiras.

Pouco tempo passou após a invasão colonial até que os portugueses descobrissem que as terras recém-invadidas tinham potencial de oferecer riquezas outras do que o extrativismo vegetal nativo. Minas poderiam ser abertas, lavras trabalhadas e grandes plantações iniciadas. Para tanto, contudo, seria necessário outro tipo de mão-deobra, especializada nesses outros trabalhos e inexistente nas Américas. Seria necessário mão-de-obra africana.

\footnotetext{
${ }^{1}$ Texto de autoria coletiva elaborado para o projeto de extensão "Diálogos Comunitários Calunduzeiros", Fazem parte do projeto, em ordem alfabética: Adélia Regina da Silva Mathias, Aisha Angele Leandro Diéne, Andréa Letícia Carvalho Guimarães, Ariadne Moreira Basílio, Clara Jane Costa Adad, Danielle de Cássia Afonso Ramos, Francisco Phelipe Cunha Paz, Gerlaine Torres Martini, Guilherme Dantas Nogueira, Hans Carrillo Guach, Iyaromi Feitosa Ahualli, Luís Augusto Ferreira Saraiva, Nathalia Vince Esgalha Fernandes, Tania Mara Campos de Almeida.
} 
Revista Calundu - Vol.3, N.1, Jan-Jun 2019

Portugueses já comercializavam com africanos desde muito antes de sua chegada às Américas. E desses, já compravam bens manufaturados, produtos agrícolas e pessoas. Igualmente, já tinham estabelecido colônias na África central e já ensinavam sua língua e seus costumes por lá. Grandes navegadores que eram trazer africanos escravizados ao Brasil não seria uma tarefa difícil. Tampouco haveria de ser tão difícil subjugá-los por aqui, afinal, cativeiros já existiam.

A historiografia oficial guarda poucas referências sobre este episódio de nossa história, mas os primeiros africanos que chegaram escravizados ao Brasil dividiram cativeiro com indígenas. $\mathrm{E}$, apesar do fato de que os portugueses não valorizavam sua associação, esses dois grupos populacionais dominados construíram vidas juntos. E realizaram trocas uns com outros. Trocas, inclusive, de conhecimentos sobre a terra, sobre a flora, sobre a fauna e sobre suas religiões, que, para ambos os grupos, focavamse no culto à natureza.

Povos descendentes de africanos no Brasil, ainda no presente, muitas vezes reconhecem este contato original entre indígenas e seus antepassados em suas culturas. Assim, elementos culturais de origem indígena são encontrados em festividades de matriz africana. Exemplos fáceis de pensarmos são a presença de raízes, como a mandioca, originalmente usada na culinária indígena, nas comidas que entendemos como de origem afro-brasileira (ex.: bobó de camarão baiano).

O contato original e o fato de que os indígenas eram os donos originais da terra no Brasil é também comumente lembrado nos terreiros das religiões afro-brasileiras, pela presença dos cultos aos caboclos. Nos rituais afrorreligiosos do Brasil, caboclos são os antigos indígenas, sempre muito reverenciados. E essa reverência vai além de apenas cantigas, danças e cumprimentos, sempre muito elaborados. Comidas de orixás levam ingredientes ensinados por indígenas. A natureza e a paisagem deificadas têm também aspectos indígenas. Os segredos da terra brasileira, finalmente, foram aprendidos pelos africanos junto aos indígenas.

Mas conhecimentos não foram apenas trocados entre indígenas e africanos. Com efeito, não devemos esquecer que ambos esses grupos foram colonizados pelos portugueses e, toda colonização, implica também em ensinamento forçado de costumes. Assim, indígenas e africanos aprenderam uns com os outros, mas também com os portugueses. E aprenderam também sobre comidas, pois cozinhavam para os portugueses; sobre as histórias dos reis de Portugal, pois eram estes seus senhores 
maiores; sobre as vontades dos portugueses, que tinham que satisfazer. E sobre a religião dos portugueses também, que era a religião católica.

É preciso neste ponto fazermos uma pausa reflexiva, para lembrarmos que, durante a colonização, a Igreja Católica não foi passiva. Não se tratava apenas da religião dos portugueses, mas também de uma instituição colonizadora com direito próprio (o direito canônico), com conhecimentos próprios, com modos de entender o mundo próprio, etc. Tudo isso tinha grande força durante a colonização, de modo que devemos sempre nos referir à colonização do Brasil como uma empresa de portugueses e da Igreja Católica.

A organização católica cabe dizer, era também balizada pela figura do rei de Portugal, via Regime do Padroado. Na prática, o padroado era um contrato firmado entre a Santa Sé (àquele momento a instituição máxima do Catolicismo, que veio a ser substituída juridicamente no presente pelo Estado soberano do Vaticano) e o rei de Portugal, que outorgava a este o controle total da Igreja Católica em sua Colônia americana - ou seja, no Brasil. Isto é, em outros termos, dizer que o rei português assumia no que tange ao Catolicismo praticado no Brasil Colônia, o lugar por direito reservado ao Papa católico, com a exceção de não alterar a lógica de rituais. Poderia, ainda assim, indicar padres, controlar dioceses, etc. E poderia mesmo aceitar dentro das igrejas elementos oriundos das religiosidades dos outros povos dominados. Um exemplo disso no presente é a presença de atabaques em algumas cerimônias católicas ainda hoje realizadas em igrejas do Pelourinho, em Salvador/BA.

Como dominadora, no entanto, não deve ser vista como surpresa a indicação de que elementos do catolicismo foram absorvidos em maior medida pelas religiões dos povos dominados (fato até certo ponto entendido como sincretismo religioso ${ }^{2}$ ). Religiões como a Umbanda, o Candomblé e o culto ao Santo Daime, por exemplo, organizam-se de forma análoga a igrejas (possuem templos construídos para receber cerimônias religiosas, abrem-se ao público até certa medida e mesmo que guardem segredos iniciáticos, possuem um calendário mais ou menos fixo de celebrações), ainda

\footnotetext{
${ }^{2} \mathrm{O}$ sincretismo religioso é um fenômeno que implica na mistura de aspectos (crenças, rituais, etc.) de uma religião com outra(s), o que pode acontecer ou não em um contexto de colonização ou outra relação de poder.
} 
no presente, mesmo que se orientem por matrizes religiosas africanas e ameríndias. A congada é, por sua vez, uma celebração católica dedicada ao rei de Congo ${ }^{3}$ e sua corte.

Assim, a integração no Novo Mundo exigia o desenvolvimento de estratégias para a própria sobrevivência humana e para a manutenção de culturas e tradições. Por isso desse encontro entre africanos e indígenas com os seus senhores, que exploravam seu trabalho e aos quais deviam submissão. Houve trocas significativas de conhecimentos, seja na forma de assimilação de saberes pela imposição dos portugueses na relação de dominação decorrente da escravidão, seja na forma do sincretismo, em que os traços culturais originais e estrangeiros se combinavam tão intimamente que o resultado era um todo cultural novo, produto também de uma relação de dominação, e potencialmente, uma técnica de sobrevivência de quem se encontrava em posição hierarquicamente inferior.

Dessa forma, na América colonial, pessoas submetidas a um mesmo sistema de dominação tiveram que lidar com as tensões inerentes às diferenças entre as várias etnias, e com aquelas advindas do sistema escravista. Elaboraram, portanto, formas de organização social que incorporaram contribuições africanas, indígenas e influências dos senhores de origem europeia. Ao lado da diversidade dessas contribuições, as determinações do sistema escravista foram fundamentais na elaboração desse diálogo entre culturas.

\section{Referências Bibliográficas}

SANTOS, Edmar. O poder dos candomblés: perseguição e resistência no Recôncavo da Bahia. Salvador: EDUFBA, 2009. Livro digital em formato Amazonkindle.

SILVEIRA, Renato. O Candomblé da Barroquinha: Processo de constituição do primeiro terreiro baiano de keto. Salvador: Edições Maianga, 2006.

SOUZA, Marina de Mello. Reis negros no Brasil escravista: história da festa de coroação de rei congo. Belo Horizonte: Editora UFMG, 2002.

Recebido: 05/05/2019

Aceito: 13/05/2019

\footnotetext{
${ }^{3}$ O Congo (que pode ser grafado Kongo) aqui citado não é o atual país africano, mas foi um antigo reino, localizado ao norte do centro da atual Angola. Este reino já realizava comércio com Portugal durante o período da colonização brasileira e muitos africanos vieram escravizados de lá.
} 